\title{
Rights of Labourers in Islam: Bangladesh Perspective
}

\author{
Hoque Kazi Arshadul \\ Department of Law International Islamic University, Chittagong, Bangladesh \\ Email: islamm.saidul@yahoo.com
}

How to cite this paper: Arshadul, H. K. (2018). Rights of Labourers in Islam: Bangladesh Perspective. Beijing Law Review, 9, 345-356.

https://doi.org/10.4236/blr.2018.92022

Received: May 3, 2018

Accepted: June 24, 2018

Published: June 27, 2018

Copyright $\odot 2018$ by author and Scientific Research Publishing Inc. This work is licensed under the Creative Commons Attribution International License (CC BY 4.0).

http://creativecommons.org/licenses/by/4.0/

\begin{abstract}
Rights and protection of workers is very important for any organization for achieving success and desired profit and also for smooth running. As a complete code of life Islam describes the rights and duties of the workers and employers. It places substances in dealing with protection accorded to workers. Employment is regarded as worship in Islam that requires observing full dedication, sincerity and commitment from both the workers and the employers. Internationally rights of the labourers are embedded in various international documents such as "Universal Declaration of Human Rights" and in the "Conventions and Recommendations" of the International Labour Organization. All states have their own labour law and policy to protect and guide both the employers and employees. Bangladesh has its own labour law and policy to regulate its labourers and employers and organizations smoothly. The major law regarding labourers in Bangladesh is the Bangladesh Labour Act 2006 that covers almost all rights and duties of Bangladeshi workers and employers. Islam is that kind of religion which always plays vital role upon Muslims in their daily affairs. In Muslim majorities countries the values of Islam keep strong influence on the laws and practices. This article examines the provisions of rights of the workers in Islam. As a Muslim majority country how far does Bangladesh incorporate or comply with the Islamic rights provisions of labourers. The main purpose of this article is to reveal the notion of workers' rights and protection which is enjoined to them under Bangladeshi labour law that has long been accorded by the Islam. Analytical approach is taken as methodology to reach the aim of the paper.
\end{abstract}

\section{Keywords}

Labourer, Bangladesh, Islam, Rights, Worker

\section{Introduction}

Work or labour is highly valued in the Islam. Laour is a form of worship. Islam 
considers labour as a virtuous endeavor. It is mandatory upon every people who have the ability to do any work. "The seeking of halal (legitimate) earnings is a compulsory after obligatory prayers and other duties in accordance with a hadith." (Baihaqy) Islam has set up laws to regulate labouers. The purposes of Islamic labour laws are to prevent the labourers from exploitation and mistreatment. Islam clearly defined workers' rights and showed the way for fulfillment and protection of those rights. When one fulfills these rights he serves the creator. He will be rewarded by the almighty because these rights are specified by Him and His messenger (pbuh). Bangladesh as a Muslim majority country has a significant connection with Islam in her everyday functions. Constitution of Bangladesh declares Islam as her state religion (Article 2A, Constitution of the People's Republic of Bangladesh). But it was a colonial country; most of the laws were enacted at that period. "The absence of Islamic principles in labour codes stems from the fact that most of the present Muslim countries were colonized at some point in the past century, and post-independence labour codes were usually just transplanted from the colonizing European nations without linking them to Islam" (Ahmad, 2011). Unique feature of Islamic labour provisions is the dignity of the laboures. Islam teaches that all people are equal and should be respected and treated equally. Allah says: "O mankind! We created you from a single (pair) of a male and a female." (Al-Hujurat 49: 13). There are a lot of prophetic texts in this regard. Prophet (pbuh) said in his last sermon: "O people, indeed your Lord is one and your father is one. Behold, there is no superiority for an Arab over a non-Arab, nor for a non-Arab over an Arab, nor for a white person over a black person, nor for a black person over a white person, except through piety." (Musnad Ahmad, 2012). High regard is given for works in Islam. The worker who earns his own living is a respectable person in Islam. The workers should be treated with dignity and honor. The Prophet (pbuh) always showed respect to workers. There is a history regarding respect of the labourers. "Our Prophet (peace and blessings be upon him) kissed the hands of a labourer who showed him his rough hands due to his hard labour" (Abu Dawud, 2008). Workers must be treated with dignity and respect, fairly and humanely. It is a religious duty in Islam. If anyone fails to treat the labourers properly he will be given punishment and will go to the hell. The dignity of workers provides values in labour laws and practices. Kindness to workers is the teachings of Islam. Allah says: "Do good to parents, kinsfolk, orphans, those in need, neighbors who are near, neighbors who are strangers, the companion by your side, the way-farer (you meet) and those whom your right hands possess..." (An-Nisaa' 4: 36-37). Those whom your right hands posses' denote the workers. The Messenger (pbuh) said: "He upon whom his brother has a right, be it of the nature of money or honor, let him compensate for it before he is made to compensate for it on a day when there will be neither dinar (then currency of Makka) nor dirham (then currency of other Arab countries) to deal with. Instead, if he has a good deed in his account it will be taken away from him and given to the person he 
had wronged. And if he has no good deeds in his account, sins of the other person will be taken from him and added to his account" (Bukhari, 1997). The Prophet translated God's labour policy into reality through his own programs. In this way, he protected the lower class jobs from any social disgrace and heightened the dignity of labour in general.

\section{Literature Review}

A number of books and articles of both national and international perspective are critically reviewed to find out the facts and knowledge gaps of the research. (Masud, 1998) depicts Islamic philosophy regarding labour along with the Quranic and Sunnatic texts. He discusses the social dignity of the workers in Islamic society, relation between employers and workers in Islam and duties/qualities of the workers in Islam. (Mondol \& Mondol, 2009) discuss the labour rights before $2^{\text {nd }}$ world war and evolution of labour rights with the emergence of ILO. They further state various labour rights enumerated in the UDHR, ICCPR, ICESCR and other international human rights conventions or treaties and documents. The authors draw attention to the contribution of Islam in respect of labourers' work. (Faruque, 2009) critically investigates the current status and evolution of industrial rights in Bangladesh. (Ahmad, 2011) says that Islam can be a basic source for adopting and creating a Labour Code in Muslim countries that meet the needs of modern era.

\subsection{Rights of Workers in Islam}

Islam plays a significant role for the protection and promotion of labour rights. On the other hand the remarkable aspects of Islamic labour provisions are that it clearly identifies the duties of workers and thus creates a balance in labour environment. Islam says about almost all kinds of labour rights. The most significant workers' rights are discussed as follows.

\subsubsection{Clear and Proper Agreements for Ensuring Justice}

Justice in Islam is a fundamental concept of Islamic Legal system. It incorporates justice not only in this world but hereafter and in this life it emphasis on the human rights and economic justice. The Islamic concept 'Justice' is founded not on the worldly matters only it also includes religion as the foundation, so Islam forbids to take benefit of the weaker partner and simultaneously emphasizes on to ensure just economy. Islamic law directs the masters and employers to do fair treatment to the servants and workers. "The Islamic emphasis on social justice is expressed through the law of trade, which includes the dealings between employers and workers." (Hascall, 2013). For ensuring protection of all parties from injustices in any transaction, Islam requires that they must come under a contract which may be written or oral but written is more preferable. "The Quran directs people to keep their promises after they make them (02: 177, 23: 08, 70: 32)." At another place, "Quran directs people to fulfill their obligations (05: 01), 
(Al-Ma'idah 5: 1)" because "the question will be asked on the Day of Reckoning whether one fulfilled one's obligations or not (17: 34)." "Quran also requires that a person, if he has entered into a contract, must fulfill the obligation, and that Allah dislikes a person who says or contracts to do something but does not do the same (61: 2-3)." Contract creates mutual rights and obligations where the employer provides some benefits like. In another hadith, "People should abide by their agreements unless there are conditions in the agreements which are unlawful and not in accordance with the code of Islam," (Tirmidhi, 1983) and another hadith says, "Islam does not permit any agreement which is to the detriment of any party." (Majma uz Zawaid) Contract is in effect and will be continued if the worker and owner do not do any unlawful. If there is any gross violation or misconduct employer has all the rights to terminate the worker. Contract allows the worker with certain conditions to resign or change the job if there is available option. Prophet says, "If you pledge an oath for something and a better alternative comes your way, break the oath and atone for it and do what is better." (Bukhari, 1997) Contract can be revoked by any party if the rules allows. Revocation can be bilateral or unilateral. The Islamic rules on contract as well as the Quranic and hadith provisions on the point let people inform that the contracts of employers and employees are to be covered by the said provisions so that none of the labourers or the employers is deprived of their reciprocal rights and duties. The provisions seem to be meaningful in the sense of ensuring the rights and duties of both the parties to a contract so that peaceful environment is created and maintained in the society.

\subsubsection{Equality and Non-Discrimination}

Islam never allows discrimination on the basis of race, sex, race, colour and so on. It also says "the measure of nobility is only taqwa, that is, doing the right deeds and fearing Allah (49: 13)," and in all other fields all are equal. There is no prohibition for women employment in Islam, as Allah says; "For men there is reward for what they have earned (and likewise) for women there is reward for what they have earned (04: 32). Never will I suffer to be lost the work of any of you, be the male or female (03: 195)." This verse states a clear rule of Islam that women are equal in workplace and must not be discriminated by the employers on basis of gender. "Shifa Bint Abduallah was so skilled in public administration that Umar appointed her a market inspector/supervisor of the Medina Market." "She was also the first woman teacher in the early Islamic era." "She was heading the institution of Al-Hisbah" ("role of the state"). Her duties included "making sure that scales were just and accurate, and that transactions were carried out according to the rulings of Islam.” (Ahmad, 2011) Scope in Islam for women to participate in economic or financial activities is quite high. Occupation in textile industry, the largest and market-orientated industry, was sometimes monopolized by women. (Shatzmiller, 1997) argued that "the evidence of the late medieval period, 11th-15th centuries, indicates women's participation in the labour 
market as both considerable and diversified. In fact, their involvement and skills seem to have been more sophisticated and wide ranging than those of medieval European women." Women participated in labour market at the Islamic era. They involved in profitable business. They did manual, technical, skilled, unskilled, trade promotional activities. "The trades and occupations which Muslim women exercised, the professional and unskilled tasks they performed and the commercial activities and deals in which they were involved, reflected a high degree of participation, specialization and division of labour." (Shatzmiller, 1997) Merit, skill and performance are the basis of Islamic recruitment policy. It decreases nepotism as a result there will be no discrimination. Rule for hiring workers is laid down in the holy Quran in very simplified way. "The best of men for you to hire is the strong (competent) and the trustworthy (28: 26)." The Prophet says, "if you give a job to someone who is not knowledgeable, just wait for the destruction" (Bukhari, 1997). Another hadith goes, "whoever is appointed to manage the affairs of a Muslim community and then he appoints someone basis of nepotism, he will therefore be condemned by Allah." (Hakim, 1990) Duty of the employer in Islam is to look for the best one. Umar said (the $2^{\text {nd }}$ Khalifa of Islam), "If a person of lesser ability is appointed when a better one is available; his action would be tantamount to betraying God, Prophet and the people." (Ahmad, 2011) Keeping in view the Islam's focus on knowledge and learning, (Baihaqy) training for workers must be provided by employers for the benefit of the trade. Hadith of "seek knowledge from cradle to grave" (Bukhari, 1997) gives indication of ever learning and from that indication it can be inferred as workers' training in workplace "Islam supports the apprenticeship model of learning." (Akdere et al., 2007) "The practice of apprenticeship is also obvious in the story of Moses and Khidr (another learned man) with whom Moses lived for some days to acquire knowledge (18: 65).” (Ahmad, 2011)

\subsubsection{Working Hours and Its Conditions}

Islam is of the view that there must be time limit of working hour so that the worker will not be overburdened. Without necessary help worker cannot work extra hour. This rule is laid down in the Quran and Hadith. "Allah only assigns a soul something that it can cope with (02: 286)," and there is a story in the Quran regarding extra load. Shu'ayb is the employer and he tells Moses that "I don't want to be hard on you (by placing more burden of labour on you) and you will find me an honorable man, if Allah so wishes (28: 27)." These verses clarify that Allah (SWT) ordains not to overburden the labourers, The Almighty never overburdens His creations, that is why His followers who want righteousness and honour must follow Him and they have to treat their labourers or subordinates with ease. The following hadith narrates similar approach: "Your servants are your brothers whom Allah has placed under your authority. Whosoever has one under him, should feed him of what he eats, clothe him of what he clothes himself, and must not burden him beyond his capacity/ability. But if you do 
burden them beyond their capacity, then help them." (Bukhari, 1997) "Manazir Ahsan Gilani, a leading Islamic scholar, is of the view that the phrase, 'and must not burden him beyond his capacity/ability' should be used in determining the duration and nature of work." (Syed \& Ali, 2010) The above hadith clearly states that employer cannot overburden his workers. Where there is overtime there is extra allowance. "However, excessive overtime and overburdening a worker may be hazardous for a worker's health, and anything counterproductive cannot be supported beyond normal lines." (Ahmad, 2011) Another hadith says, "giving light work to subordinates will be rewarded on the Day of Judgment." (Kanz ul Ummal)

Islam directs to make the working place safe, hygienic and without any hazard. The rule is laid down not only in the Quran but also in the Hadith. The holy Quran says, "yet don't expose yourselves to ruin through your own hands. Do good; God loves those who act kindly (02: 195)." Safe condition in a workplace must be ensured by the employer is referred by this verse. Ibn Hazm reported a hadith that "It is the duty of the employers to take only such work from their employees which they can easily do. They should not be made to labour so that their health is told upon." Another tradition is that "don't burden your worker with the work that he or she cannot endure.” (Bukhari, 1997) General guidelines are provided by The Quran regarding "rest and leisure and considers it a basic right (28: 73, 33: 53)." The Prophet said, "Man owes something (of his labour and energies) to himself, something to his body, something to his wife (family), something to his eye (psychic or aesthetic satisfaction)." (Tirmidhi, 1983) Rest and leisure are treated as core rights as referred by the above texts. Lawful enjoyment and recreation is encouraged by Islam and it is evident by following hadith "Allah loves to see the sign of His bounties on his creatures", (Ahmad, 2011) indicates that people should spend earnings for their enjoyment. At that time a lot of troops were posted in remote station that was why they were given leave with payment once or twice in a year. "Umar had issued standing orders that no soldier should be compelled to stay away from his home/family for more than four months." (Zulfiqar, 2007)

\subsubsection{Wages}

Islamic law takes a very strict approach to payment for services (Musannaf, 2017). According to the Quran wages are a right, not kindness from the owner, The Quran says, "those who believe and perform honorable deeds (good work)... their earnings will never be withheld from them (95: 06)." Anticipating modern notions of express or implied contracts of employment, the Prophet also "forbade the hiring of a worker without the prior fixation of wages for the work." (Ahmad, 2011) The above instances from Quran and Hadith show that a worker should be explicitly told about the wages he is going to get after the completion of his work. Specification of wages may be oral or in written form. Wages must be sufficient to provide the basic necessities of life for the workers. In this way, 
Islam talks not only about a minimum but also a just or "living" wage. There is a verse in Quran which says that a "family head (father) should support women (after divorcing them, through alimony for children) and clothe them properly (02: 233)." It can be inferred, through Qiyas, from the verse that "compensation should meet at least the cost of food and clothing (the basic necessities at the time of revelation of Quran) in accordance with the norms of the time." (Muslim, 2007) Different traditions from the Prophet deal specifically with the subjects. The Prophet said that "an employee (male/female) is entitled to at least moderately good food and clothing and not being burdened except what he/she can bear" (Majma Uz Zawaid) and "make them satisfied in regard to their basic needs." (Bukhari, 1997) In another instance, the Prophet said, "Those working under you are like your brothers whom God has made your subordinates. So he who has his brother working under him let him feed what he feeds himself and clothe him what he clothes himself with." "Islamic history shows that Umar fixed the wages for military personnel, and during his period, salaries were also revised on the basis of several criteria such as length of service, best performance, and knowledge level." (Abu Dawud, 2008) These ahadith shows that Islam refers both minimum and ideal/just wage but it specifies the minimum wage so that the basic needs of a worker are met. In another hadith it is mentioned that "whoever takes a public job and has no house (of his own), should have one (i.e., government should provide housing). If he is not married, he should get married, and if he does not have something to ride, he should have one (provisioned by the government)". It appears that Islam requires the employers to provide the workers with housing, medical facilities, job education or training, transportation, and meals. By focusing more on the necessities and minimum level of living conditions (which can be different from time to time and place to place, making it easier to define them), it seems that "Islam cares more about the real wages which need to be maintained or increased in comparison with the nominal or monetary wages." In conclusion, setting a minimum wage at a "fair," "just," or "living wage" level is quite in line with Islamic principles. The principle in fixation of wages is that wages should be set keeping in view the prevailing conditions such as inflation, regional price differences, and needs. It is related that Umar used to determine wages according to the conditions prevalent in the city and the employees' personal needs. "This is also evident in a tradition where the Prophet gave double the share in ghanimah (war spoils) to the persons with families compared to unmarried persons." (Majah \& Muhammad, 1993) Another principle is the punctual and timely payment of wages. It is narrated in a hadith that the Prophet said, "Give employee his/her wages before the sweat is dry on him." (Majah \& Muhammad, 1993) In another hadith, it is related, "The rich, despite his riches, cannot delay of payment to the worker, for it is a crime." (Bukhari, 1997) These Ahadith show the general principle that wages need to be paid promptly and an employer cannot unduly withhold the wages of an employee. However, workers and employers can negotiate the payment of wages on 
daily, weekly, fortnightly, or monthly terms. Another principle regarding wages is their full payment. Quran says, "Never will I suffer to be lost the work of any of you, be he male or female (03: 195)", and the Prophet said that "Allah would be enemy of three persons on the day of Resurrection and one of them would be the one who hired somebody for some stipulated wage, took full advantage of his labour and then did not give him his due." (Bobo, 2008) The third person is compared in hadith to the one who made a free person a slave and sold him for money. This hadith shows that not only a worker should receive full wages for his/her work, but also it prohibits forced labour. "Withholding of somebody's remuneration is considered one of the gravest sins. This hadith also sheds some light on the issue of wage theft." (Bukhari, 1997)

The Prophet once said "Man has no right in the share in which God has no right. God's share is his command to give everyone his/her due and not to encroach on what belongs to another, and it is narrated about the Prophet that he never gave a worker less than what was due." (Muslim, 2007) Lastly, there is also the issue of equal pay for equal work. Islam provides for equal pay for equal work. Islam is of the view that every work, whether right or wrong, is rewarded or punished and in paying for the work, it does not differentiate between male and female, white and black, and does not allow any discrimination on race, religion, origin, and language or ethnicity backgrounds. Allah says that "I never cause loss to the labour of a worker, be that male or female (03: 195)", and in another place, He says that "to them, we shall pay the price of their works and they will not be paid diminishingly (11: 15)". In some other verses, Quran tells that "whoever has done good work and bad work will see it placed before him (99: 07-08, 18: 49)." All the above verses show that Islam wants a worker to be paid for his work without any over or under valuation. It does not discriminate on the basis of sex, religion, race, ethnicity, region or origin, etc.

\subsubsection{Social Security}

Islam not only talks about equitable distribution of wealth in the society but also gives the whole population a right to basic standard of living through basic state pensions. The basic standard of living is ensured through imposition of the Zakat on the rich with the aim that "this wealth may not become a fortune used by the rich among you (59: 07)". Zakat is to be taken from the affluent and then distributed and spent on the welfare of the poor. "It should be collected from their rich and distributed among their poor." (Chapra, 1983) As Zakat is one of the five pillars of Islam, and it is obligatory in nature, it is expected that a minimum standard of living could be ensured if people pay Zakat on their belongings above the minimum (nisab). The Islamic system provides a social safety net for the needy through Zakat. Islam makes it a collective responsibility of the society to provide the deprived with all basic necessities of life. It is state's responsibility to provide everyone a basic state pension through collection of Zakat (poor tax) and imposition of other taxes if Zakat funds are not enough for meeting expend- 
iture. Although Zakat is obligatory on Muslims only, it is spent on the welfare of all citizens of the state whether they are Muslims or non-Muslims. Zakat is the social security institution created by Islam. According to Islamic jurists, Zakat may be used to provide training to the unemployed and also in job rehabilitation programs. Zakat may also be used as an income support program. Labourers are the poorest people in the society. They are able to take zakat money. Proper distribution of zakat to the workers can be a good move to improve the conditions of the workers.

\subsubsection{Profit Sharing}

Profit sharing is one of the best provisions for the labourers in Islam. "The proponents of Islamic economic and finance systems have written extensively on the establishment of profit sharing or stock ownership schemes in firms." (Chapra, 1992) The workers should be given the profit. The basic principle at work is that "every firm should be required to establish a profit-sharing scheme for its employees." (Siddiqi, 1983) Islam appreciates joint ventures. "Islam allows joint ventures between two parties where one party provides the capital and the other provides labour or services, and profits are divided as agreed before (called $\mathrm{Mu}$ darabah, it is a specific form of partnership or Musharakah)." (Udovitch, 2003) "It also includes labour-only partnerships where the only investment is the skills that labourers have." (Chapra, 1983) Chapra has argued that "profit may be divided into two parts: bonuses and other benefits, where the latter can be used for improving working conditions and providing training to workers, allowance for children's education and food subsidies." (Bukhari, 1997) These benefits also include retirement and health benefits as well as paid vacations, which positively affects workers' motivation and job satisfaction.

Ahadith of the Prophet are there in which employers are required and persuaded to share the product and profits with the workers. One hadith says, "If your servant prepares food for you and brings it to you, he has undergone the torment and agony of smoke and heat. You should therefore, ask him to sit and participate in the food. If you have guests, reserve some of the food for the servant, at least a morsel or two." (Majma' al-Zawa'id, 2015) At another place the Prophet said: "Pay the workers part of the food grains produced through their efforts; labour as the servant of God cannot be deprived of the produce." (Zulfiqar, 2007) This is a simple and straight rule that a firm has to share the profits with its employees. The idea of bonus is enshrined in the above quoted ahadith. Another principle discerns from the first hadith that if the employer is not earning much profit, he should still give workers some of share of the profits.

Moreover the concept of profit sharing is also present in the obligatory pillar of Zakat (poor tax). Zakat is a way of sharing the riches with the poor; Quran considers it as "a right of the poor (51: 19)," and it is deducted as specified by Quran and Sunnah. The more a person contributes to the society through labour or capital, the less he or she gets taxed and less profit is shared among the 
masses.

\subsection{Labourers' Rights in Bangladesh}

The Labour Code, 2006 is the principal law governing workers' rights and protection in Bangladesh. This code regulates the conditions of employment by laying down the minimum and basic terms and conditions of the service, setting out condition of employment and service, employment of children and adolescent, maternity benefit, health and hygiene, safety of building and machinery, precaution in case offire, welfare measures, hours, holiday, leave, payment of wages, minimum rates of wages, compensation for injury, trade union, collective bargaining agent, settlement of industrial disputes, participation fund and welfare Fund, provident Funds for workers, apprentices, Penalty for non-compliance. Though this law is applicable to the whole of Bangladesh, but exceptions make the law applicable only for the formal labourers. Most of the workers are informal to whom labour law is not applicable. Implementation of the labour law properly in Bangladesh remains far away. Workers cannot enjoy their legal rights. It can be said that labour law is in book not in practice.

\section{Conclusion}

Islamic teachings might have appeared prominently in labour and employment laws in muslim countries. Despite that, labour and employment laws of Muslim countries do not fully reflect the Islamic provisions of labour relations. Islam, as a complete code of life of a Muslim, can have a notable impact in modifying and accepting labour laws in Muslim countries that may not only comply with the international labour standard but also make convenient provisions for improving the standard of living of general labourers. Muslims believe that the religious basis of the labour law may make it more authentic, resonating better with the Muslim population especially Islamic jurists and thinkers, and giving workers, employers, and citizens a sense of ownership and involvement in the labour law system. The Islamic injunctions relating to labour rights and duties are forms of moral suasion, at least Muslims think so. They may be analogized to International Labour Organization (ILO) labour standards. Islam encourages states to play a role in regulating the labour market, and secondly, these religious and moral persuasions act as forceful legal injunctions with regard to fundamental Muslim belief of the hereafter (al-akhirah). Life hereafter of a Muslim is in Islamic view successful only if he is successful in the afterlife, and this success depends on whether he observed the Islamic and moral standards encouraged by Islam throughout his life. Islam requires its believers to be aware of the consequences of each and every worldly action in the afterworld. Islamic instinct provides that all the efforts and actions Muslim will be rewarded or punished in the hereafter. This concern for the other world makes the persuasions stronger than just legal injunctions. But it also needs to be kept in mind that Islam puts equal stress on the importance of legal provisions. The clear stance of Islam is that le- 
gal provisions must have moral and ethical supports in order for it to be effective.

\section{References}

Abu Dawud, S. (2008). Arabic and English. Translated by Abu Ammar Yasir Qadhi. Riyadh: Darussalam Publishers.

Ahmad, I. (2011). Religion and Labor: Perspective in Islam, Working USA. The Journal of Labor and Society, 14. https://doi.org/10.1111/j.1743-4580.2011.00363.x

Akdere, M., Russ-Eft, D., \& Eft, N. (2007). The Islamic Worldview of Adult Learning in the Workplace: Surrendering to God. Human Resources Abstracts, 42, 355-363.

Al-Hujurat 49: 13, An-Nisaa' 4: 36-37. The Quran, English Translation of the Holy Quran by Abdullah Yusuf Ali.

https://archive.org/details/HolyQurAnYusufAliTranslation1946Edition

Article 2A, Constitution of the People's Republic of Bangladesh.

Baihaqy. Abu Bakr Ahmad b Husayn b Ali. Beirut: Dar al-Kitab al-Araby.

Bobo, K. (2008). Wage Theft in America. New York: The New Press.

Bukhari, S. Al-B. (1997). Arabic and English. Translated by Dr. Muhammad Muhsin Khan. Riyadh: Darussalam Publishers.

Chapra, M. U. (1983). Islamic Work Ethics. Al-Nahdah: Muslim News and Views, 3, 1-7.

Chapra, M. U. (1992). Islam and the Economic Challenge (Islamic Economics Series; No. 17, p. 254). Hemdon: The Islamic Foundation and The International Institute of Islamic Thought.

Faruque A. A. (2009). Current Status and Evolution of Industrial Relation Systems in Bangladesh. New Delhi: International Labour Organization, Sub Regional Office for South Asia.

Hakim (1990). Naisabury Muhammad b Abdullah Abu Abdullah al-Hakim, Al-Mustadrak Ala al-Sahihayn. Beirut: Dar alKutub al-Ilmiyyah.

Hascall, S. C. H. (2013). Islamic Commercial Law and Social Justice: Shari'ah Compliant Companies, Workers' Rights, and the Living Wage (p. 11). Duquesne University School of Law Research Paper, No. 2013-07. http://ssrn.com/abstract=2308089

Kanz ul Ummal, Allama Allauddin Ali Muttaqi bin Husam ud Din Al-Hindi, Translation and commentary by Maulana Mufti Ihsan ullah Shaiq.

Majah, I., \& Muhammad, A. A. (1993). Sunan Ibn-i-Majah. Translated by Tufail Ansari, Lahore, Kazi Publication.

Majma' al-Zawa'id, Majma' al-Zawa'id wa Manba' al-Fawa'id (2015). By al-Hafiz Imam Nur al-Din Ali al-Haythami, compiled by Shaykh Hussain Salim Asad ad-Darani, Dar al-Minhaj, Jeddah, Saudi.

Masud, F. U. (1998). Islame Shramiker Odhikar (Labourer's Rights in Islam). Dhaka, Bangladesh: Islamic Foundation.

Mondol, R., \& Mondol, S. (2009). Human Rights Law, Constitution Islam NGO (Manobadhikar Ain Songbhidhan Islam Ngo). Dhaka: Shams Publication.

Musannaf (2017). The Musannaf of Abd al-Razzaq. Translated by Abul Ula muhi Uddin jehangir.

Muslim, S. M. (2007) Arabic and English. Translated by Nasiruddin al-Khattab, Darussalam Publishers, Riyadh.

Musnad Ahmad (2012) Musnad Imam Ahmad bin Hanbal, Arabic and English, Trans- 
lated by Nasiruddin al-Khattab, Darussalam Publishers, Riyadh.

Shatzmiller, M. (1997). Women and Wage Labour in the Medieval Islamic West: Legal Issues in an Economic Context. Journal of the Economic and Social History of the Orient, 40, 174-206. https://doi.org/10.1163/1568520972600748

Siddiqi, M. N. S. (1983). Issues in Islamic Banking (p. 139). Leicester, UK: The Islamic Foundation.

Syed, J., \& Ali, A. J. (2010). Principles of Employment Relations in Islam: A Normative View. Employee Relations, 32, 454-469. https://doi.org/10.1108/01425451011061630

Tirmidhi, Muhammad b, 'Isa. (1983). Sunan Al-Tirmidhi, ed. 'A. 'Abdallatif, Beirut.

Udovitch, A. L. (2003). Labor Partnerships in Early Islamic Law. In M. G. Morony (Ed.), Manufacturing and Labour (pp. 307-323). Aldershot, Hant, England; Burlington, VT: Ashgate.

Zulfiqar, A. A. Z. (2007). Religious Sanctification of Labor Law: Islamic Labor Principles and Model Provisions. University of Pennsylvania Journal of Labor and Employment Law, 9, 426. 